\title{
Study of the BPP7a Peptide and its $\beta$-Cyclodextrin Complex: Physicochemical Characterization and Complete Sequence Specific NMR Assignments
}

\author{
Ivana Lula, ${ }^{a}$ Frederico B. de Sousa, ${ }^{a}$ Ângelo M. L. Denadai, ${ }^{a, c}$ Danielle Ianzer, ${ }^{b, d}$ \\ Antônio C. M. de Camargo, ${ }^{d}$ Robson A. S. Santos ${ }^{b}$ and Rubén D. Sinisterra ${ }^{*, a}$
}

${ }^{a}$ Departamento de Química, Instituto de Ciências Exatas and ${ }^{b}$ Departamento de Fisiologia e Biofísica, Instituto de Ciências Biológicas, Universidade Federal de Minas Gerais, Av. Antonio Carlos, 6621, 31270-901 Belo Horizonte-MG, Brazil

${ }^{c}$ Centro Federal de Educação Tecnológica (CEFET-MG, Campus VII), Av. Amazonas, 1193, Vale Verde, 35183-006 Timóteo-MG, Brazil

${ }^{d}$ Center for Applied Toxinology (CAT-CEPID), Instituto Butantã, Av. Vital Brasil, 1500, 05503-900 São Paulo-SP, Brazil

\begin{abstract}
O heptapeptídeo BPP7a, p-Glu ${ }^{1} \mathrm{Asp}^{2} \mathrm{Gly}^{3} \mathrm{Pro}^{4} \mathrm{Ile}^{5} \mathrm{Pro}^{6} \mathrm{Pro}^{7}$, forma um complexo de associação com a $\beta$-ciclodextrina na razão molar 1:1. O peptídeo e a sua forma complexa foram caracterizados por dicroísmo circular (CD) e titulação calorimétrica (ITC), as quais sugerem uma interação muito fraca entre a $\beta$-ciclodextrina e o peptídeo. Espectros de ressonância magnética nuclear $(\mathrm{NMR}) \mathrm{de}{ }^{1} \mathrm{H}$ a 400 e $600 \mathrm{MHz}$ foram obtidos para o peptídeo puro e para o complexo com $\beta$-ciclodextrina e com estes foi possível a atribuição de todos os sinais de ressonância de hidrogênio do peptídeo. Experimentos de espectroscopia ordenada de difusão de alta resolução (HR-DOSY) foram conduzidos a fim de se confirmar a associação entre o BPP7a e a $\beta$-ciclodextrina, além de se verificar a quebra dos agregados moleculares do BPP7a devida a associação. A atividade antihipertensiva do complexo BPP7a/ $\beta$-ciclodextrina foi avaliada em ratos naturalmente hipertensivos (SHR), mostrando resultados melhores do que os do peptídeo BPP7a puro.
\end{abstract}

The BPP7a heptapeptide, p-Glu ${ }^{1} \mathrm{Asp}^{2} \mathrm{Gly}^{3} \mathrm{Pro}^{4} \mathrm{Ile}^{5} \mathrm{Pro}^{6} \mathrm{Pro}^{7}$, forms an association complex with $\beta$-cyclodextrin in a 1:1 molar ratio. The peptide and its complex were characterized by circular dichroism (CD) and isothermal titration calorimetry (ITC), which showed a very weak interaction between the $\beta$-cyclodextrin and the peptide. Assignments of all hydrogen resonances of the peptide alone and as a complex were made using ${ }^{1} \mathrm{H}$ nuclear magnetic resonance (NMR) experiments at 400 and $600 \mathrm{MHz}$. High resolution diffusion ordered spectroscopy (HR-DOSY) experiments were carried out to establish the self-aggregation state of BPP7a. It was also shown that the $\beta$-cyclodextrin breaks the molecular clusters leading to complex formation. In addition, the anti-hypertensive activity of the BPP7a/ $\beta$-cyclodextrin complex was evaluated in spontaneous hypertensive rats (SHR), showing increased activity compared to that of pure BPP7a.

Keywords: bradykinin potentiating peptide, $\mathrm{p}-\mathrm{Glu}^{1} \mathrm{Asp}^{2} \mathrm{Gly}^{3} \mathrm{Pro}^{4} \mathrm{Ile}^{5} \mathrm{Pro}^{6} \mathrm{Pro}^{7}, \beta$-cyclodextrin, association complex, NMR, HR-DOSY

\section{Introduction}

Serpent venom, especially from Bothrops jararaca, contains small-molecule peptides which greatly enhance the smooth-muscle contraction induced by bradykinin. ${ }^{1}$ These peptides, called bradykinin potentiating peptides (BPPs), have also demonstrated the ability to inhibit angiotensin-I

*e-mail: sinisterra@ufmg.br converting enzyme (ACE). ${ }^{2-5}$ Typically, BPPs from Bothrops jararaca contain 5 to 14 amino acid residues and have similar features, such as a high content of proline residues, a pyroglutamic acid residue at the $\mathrm{N}$-terminus and the Ile-Pro-Pro tripeptide at the C-terminus. Since their discovery in the 1960's, several BPPs have been identified and also isolated. One of them is the BPP7a heptapeptide (Figure 1). ${ }^{6-8}$

In recent studies, $\mathrm{BPP} 7 \mathrm{a}$ at low dose $\left(0.47\right.$ to $\left.71 \mathrm{nmol} \mathrm{kg}^{-1}\right)$ was able to cause potent and sustained antihypertensive 


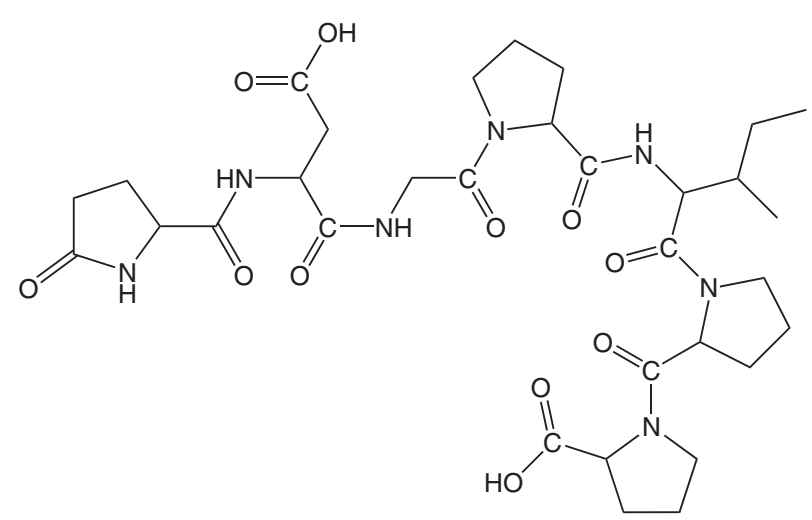

Figure 1. Chemical structure of the BPP7a peptide, $\left[\mathrm{p}-\mathrm{Glu}^{1} \mathrm{Asp}^{2} \mathrm{Gly}^{3}\right.$ Pro $^{4} \mathrm{Ile}^{5}$ Pro $\left.^{6} \mathrm{Pro}^{7}\right]$.

activity in conscious spontaneously hypertensive rats (SHR). This activity was not related to the inhibition of ACE in vitro, bradykinin potentiation or blockade of the pressor effect of angiotensin I in vivo, indicating a new target of this molecule, which may lead to the development of new antihypertensive drugs. ${ }^{9,10}$ In general, a peptide is preferentially absorved in the colon after oral ingestion. Thus, many studies indicate that colon-specific drug carriers should be used to orally deliver these macromolecules. ${ }^{11}$

Various therapeutic systems used for targeting drugs to the colon are capable of minimizing the possible drawbacks associated with drug degradation and, moreover, are able to modify the administer dose. Therefore, cyclodextrins could be used once this class of molecules is shown as a potential colon-specific drug carrier system. ${ }^{11,12}$ Cyclodextrins are neither hydrolyzed nor absorbed in the stomach or the small intestine, making them effective protectors of different classes of guest molecules. Thus, a synergic effect could be reached using cyclodextrins as drug carrier systems for peptides and proteins. In addition, cyclodextrins are able to recognize not only the size but also the shape of peptides and proteins. These molecules may be too large to be wholly included in the cyclodextrin cavity. However, these guest molecules could present hydrophobic side chains in their backbones, which can interact specifically and form inclusion or association complexes with cyclodextrins. ${ }^{13-18}$

Cyclodextrins are cyclic oligosaccharides which have a toroidal structure with a hydrophilic outer surface and a hydrophobic cavity. The hydrophilic nature of the outer surface of the cyclic structure makes them water soluble. In addition, their structure allows the formation of supramolecular complexes with organic and inorganic molecules stabilized by non covalent interactions such as: hydrophobic effects, van der Waals forces and electrostatic interactions. ${ }^{19,20}$ To date, the main use of cyclodextrins reported in the literature concerns their ability to increase the solubility of hydrophobic guest molecules. ${ }^{13-18,21-25}$
A large number of spectroscopic techniques have been used to investigate peptide and protein structures in both solution and solid state, such as circular dichroism (CD) and infrared spectroscopy. ${ }^{26-28}$ However, nuclear magnetic resonance spectroscopy (NMR) is one of the most important tools used to determine their structures. Resonance assignments form the basis of peptide structure analysis and their determination is the first step of peptide structure analysis in solution. Heteronuclear singlequantum correlation (HSQC) has been used to solve overlapping resonance problems and to assign ${ }^{13} \mathrm{C}$ NMR signals of peptides. ${ }^{29-34}$ Total correlation spectroscopy (TOCSY) experiments have been carried out to identify individual resonances associated with each spin system and to assign them to an amino acid residue. Nuclear Overhauser spectroscopy (NOESY) experiments have been applied to provide information regarding interaction and conformational changes concerning peptide structure. Diffusion ordered spectroscopy (DOSY) experiments have been used to investigate self-aggregation of a free peptide molecule and its complex with $\beta$-cyclodextrin. In addition, DOSY experiments have been used to gain insight into interactions between cyclodextrin and guest molecules. . $^{35,36}$

In this article, we report the study of the BPP7a peptide and its interaction with $\beta$-cyclodextrin using all the aforementioned NMR techniques to obtain information regarding peptide structure, self-aggregation and also its interaction with $\beta$-cyclodextrin. To better understand the nature of this supramolecular arrangement, CD spectroscopy and isothermal titration calorimetry (ITC) were performed. CD spectroscopy is one of the most valuable techniques to investigate peptide secondary structure in solution, while ITC provides the thermodynamic parameters of the complexation process. ${ }^{37-39}$ Finally, the anti-hypertensive activity of the oral pharmaceutical formulation of the BPP7a/ $\beta$-cyclodextrin complex was evaluated by radiotelemetry, monitoring its effect on the blood pressure and heart rate of SHR.

\section{Experimental}

BPP7a (p-Glu ${ }^{1} \mathrm{Asp}^{2} \mathrm{Gly}^{3}$ Pro $^{4} \mathrm{Ile}^{5}$ Pro $^{6} \mathrm{Pro}^{7}$ ), analytical purity degree was obtained from BACHEM ${ }^{\circledR}$ Bioscience Inc., USA, and $\beta$-cyclodextrin (analytical purity degree) was obtained from CERESTAR ${ }^{\circledR}$, USA. Milli-Q ${ }^{\circledR}$ water and deuterated water $\left(\mathrm{D}_{2} \mathrm{O}\right)$ from CIL-Cambridge Isotope Laboratories, Inc., were used in sample preparation. All reagents were used as received.

All BPP7a/ $\beta$-cyclodextrin complexes were prepared using the freeze-drying method: the solid-state BPP7a complex with $\beta$-cyclodextrin (called $\beta$-CD) was prepared in a 1:1 molar ratio for most NMR experiments and at 
different molar proportions of BPP7a: $\beta$-cyclodextrin for HR-DOSY experiments (8:0, 2:6, 4:4 and 6:2) with $8 \mathrm{mmol}$ of total concentration. The required amounts of BPP7a and $\beta$-cyclodextrin were accurately weighed and dispersed in Milli-Q ${ }^{\circledR}$ water and the solution was magnetically stirred at room temperature for $48 \mathrm{~h}$ before freeze-drying.

$\mathrm{CD}$ spectra of BPP7a and its inclusion compound solutions were recorded in duplicate using a JASCO spectrophotometer model J-720 at $298 \mathrm{~K}$ with a $0.1 \mathrm{~cm}$ path length cell cuvette. Wavelengths were measured from 190 to $320 \mathrm{~nm}$ with $0.5 \mathrm{~nm}$ step resolution, sweep speed of $100 \mathrm{~nm} \mathrm{~min}{ }^{-1}$ and bandwidth of $0.1 \mathrm{~nm}$. The spectra, an average of 4 scans, were processed with JASCO software. Solvent spectral subtraction was performed. Secondary structure content was calculated from the CD spectra using PEPFIT software. ${ }^{37,38}$

ITC was carried out in duplicate with a VP-ITC microcalorimeter from Microcal at 298.15 K using water as solvent. The ITC instrument was previously calibrated electrically and chemically. ${ }^{39,40}$ The titration experiments consisted of 41 successive injections of BPP7a ( $45 \mathrm{mmol})$ into the reaction cell charged with $1.5 \mathrm{~mL}$ of $\beta$-cyclodextrin solution $(4 \mathrm{mmol})$, with a time interval of $350 \mathrm{~s}$. To eliminate diffusion effects of the material from the syringe to the calorimetric cell, the first injection was discarded and subsequently a constant volume of $5 \mathrm{~mL}$ was injected with an injection time of $2 \mathrm{~s}$. The results were analyzed by the equipment software Micro Cal Origin 5.0 for ITC with subtraction of the blank experiment (dilution of BPP7a in water). ${ }^{41}$

NMR spectra were recorded on a Bruker DRX400AVANCE spectrometer operating at $400 \mathrm{MHz}$ and a VARIAN INOVA-600AS spectrometer operating at $600 \mathrm{MHz}$ equipped with a $5 \mathrm{~mm}$ inverse probe with z-gradient coil and a $5 \mathrm{~mm}$ gradient triple resonance $\left({ }^{1} \mathrm{H}-{ }^{13} \mathrm{C}-{ }^{15} \mathrm{~N} /{ }^{31} \mathrm{P}\right)$ probe, respectively. ${ }^{1} \mathrm{H}-{ }^{1} \mathrm{H}$ TOCSY contour maps (spin lock time of $85 \mathrm{~ms},{ }^{\mathrm{n}} J_{\mathrm{H}, \mathrm{H}}, \mathrm{n}=1,3,5$ ) were acquired using an MLEV-17 pulse sequence. ${ }^{1} \mathrm{H}$ NOESY contour maps were acquired using mixing times of 150 and $230 \mathrm{~ms}$. The experiments were recorded at $5{ }^{\circ} \mathrm{C}$ and no spin diffusion was observed. All NMR peptide samples were prepared in $10 \% \mathrm{D}_{2} \mathrm{O} / \mathrm{H}_{2} \mathrm{O}$ as the solvent and water suppression was achieved using presaturation and WATERGATE suppression techniques. ${ }^{42}$

Two-dimensional inverse hydrogen-detected heteronuclear shift correlation spectra were obtained using a ${ }^{1} \mathrm{H}$ and ${ }^{13} \mathrm{C}$ HSQC pulse sequence $\left[{ }^{1} J_{\mathrm{C}, \mathrm{H}}\right]$. All experiments were used to confirm the assignments of the peptide molecule and its complex with $\beta$-cyclodextrin.

All DOSY experiments were performed using the stimulated echo with bipolar gradient pulse pair sequence, modified with an introduction of a presaturation pulse for solvent signal suppression (STEBPGP1S). ${ }^{43,44}$ The duration of the magnetic field pulse gradients $(\delta)$ and the diffusion times $(\Delta)$ were optimized for each sample in order to obtain complete dephasing of the signals with the maximum gradient strength. A series of 16 STEBPGP1S spectra on $16 \mathrm{~K}$ data points were collected in each NMR experiment, and the values of $\delta$ and $\Delta$ were 3 and $33 \mathrm{~ms}$, respectively. The pulse gradients were incremented from 2 to $95 \%$ of the gradient strength in a linear ramp. The experiments were performed at $300 \mathrm{~K}$. After Fourier transformation and baseline correction, the diffusion dimension was processed. NMR data were processed and analyzed with the Bruker XWINNMR software package (version 3.5) and NMRPIPE \& NMR View software, version 5.0.3..$^{37,45-48}$

For the anti-hypertensive activity evaluation, male SHR (14-16 weeks old) weighing 250-350 g were used. All rats were obtained from Cebio (Centro de Bioterismo do Instituto de Ciências Biológicas, Universidade Federal de Minas Gerais). Free access was allowed to standard diet (Nuvilab CR1-Nuvital Nutrients) and tap water was supplied ad libitum. The rats were housed in separated cages, under controlled temperature $(298 \mathrm{~K})$, and a $12 \mathrm{~h} / 12 \mathrm{~h}$ light/dark cycle (light: 6:00 AM-6:00 PM). Before the experiments, the animals were acclimatized for 12 days in an isolated telemetry room. All experimental protocols were performed in accordance with the guidelines for the human use of laboratory animals of our institution and approved by local authorities. A telemetry system (Data Sciences International, USA) was used for measuring mean arterial pressure (MAP) and heart rate. This monitoring system consisted of a radio frequency transducer model TA11-PA C40, a receiver, a matrix and an IBM-compatible personal computer with accompanying software (Dataquest A.R.T. Gold 2.0) to store and analyze the data. ${ }^{48,49}$ Under $2.5 \%$ tribromoethanol anesthesia $(1 \mathrm{~mL}$ per $100 \mathrm{~g}$ body weight), the catheter-transducer was implanted into the abdominal aorta just below the bifurcation of the iliac arteries and the sensor was fixed to the abdominal wall. Before the experiments, the rats were housed in individual cages for 10-12 days until the telemetry tracing indicated re-establishment of $24 \mathrm{~h}$ oscillations of blood pressure and heart rate. Data were sampled every $10 \mathrm{~min}$ for $24 \mathrm{~h}$. After recovery, the SHR were randomized in three experimental groups: BPP7a/ $\beta-\mathrm{CD}(n=5), \mathrm{BPP} 7 \mathrm{a}(n=5)$ and vehicle $\beta-\mathrm{CD}(n=5)$.

Time course experiments using a SHR animal model were developed to characterize the cardiovascular effects of the inclusion compound on blood pressure and heart rate. Briefly, doses of $0.71 \mu \mathrm{mol} \mathrm{BPP7a} \mathrm{per} \mathrm{kg}$ body weight (blank experiment) and $2.02 \mu \mathrm{mol} \mathrm{BPP7a/ \beta -CD} \mathrm{complex}$ 
per $\mathrm{kg}$ body weight $(0.71 \mu \mathrm{mol}$ of BPP7a $+1.31 \mu \mathrm{mol}$ of $\beta$-CD) were administered by gavage. The period of observation consisted of $1 \mathrm{~h}$ prior to administration (control) followed by $10 \mathrm{~h}$ after oral administration of peptide or vehicle.

Data were collected every 10 min during the entire experimental period. The variation in MAP was calculated each 10 min by the difference of the MAP value and an average of MAP values collected for $1 \mathrm{~h}$ before administration of the compounds. Data were analyzed by GraphPad Prism 4.0 software (GraphPad Software Inc., USA) followed by Student unpaired $t$-test or one-way analysis of variance with Dunnett's post-test when appropriate. ${ }^{50}$ All statistical analyses differences were considered significant when $p<0.05$.

\section{Results and Discussion}

In the present manuscript, the solution analysis of the BPP7a peptide and its complex with $\beta$-cyclodextrin are described.

\section{Circular dichroism spectroscopy}

The CD spectra of BPP7a recorded with and without $\beta$-cyclodextrin are shown in Figure 2. In aqueous solution, the spectrum of BPP7a presented two negative bands at 190 and $203 \mathrm{~nm}\left(-4.89 \times 10^{-3}\right.$ and $-10.88 \times 10^{-3}$ degrees $\mathrm{cm}^{2} \mathrm{~mol}^{-1}$, respectively), and one positive band at $232 \mathrm{~nm}\left(0.33 \times 10^{-3}\right.$ degrees $\left.\mathrm{cm}^{2} \mathrm{~mol}^{-1}\right)$. Under the same conditions, the spectrum of BPP7a/ $\beta$-cyclodextrin in solution showed the same profile observed for the free peptide solution, except that all signal intensities were reduced (Figure 2). The CD spectroscopy results mainly indicate a random coil

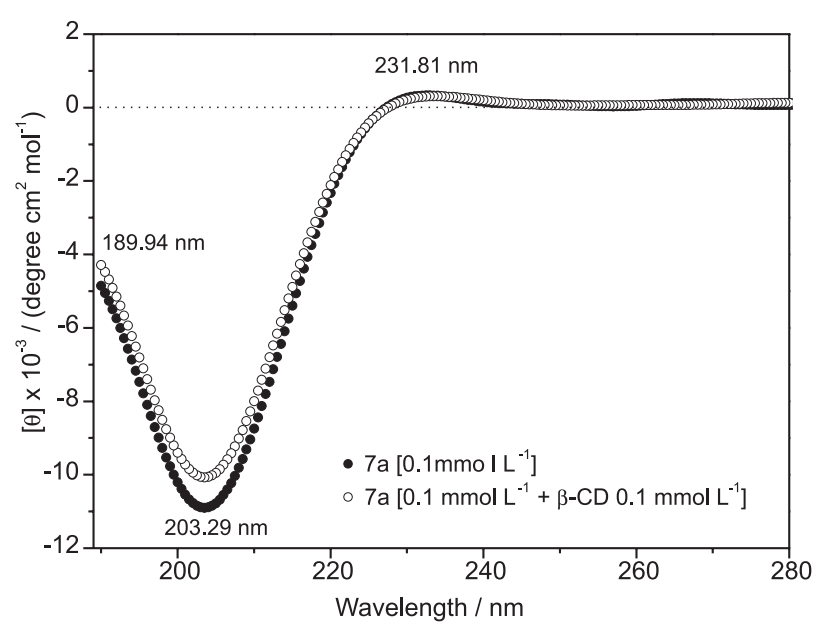

Figure 2. Circular dichroism spectra of BPP7a peptide and BPP7a/ $\beta$-cyclodextrin solutions. conformation for the peptide and its inclusion compound in solution. Deconvolution of the BPP7a spectrum showed that the secondary structure might be characterized as an equilibrium between the random coil conformation and $\beta$-structures (Figure 2). ${ }^{37,38}$ The shape of the CD spectrum of the BPP7a/ $\beta$-cyclodextrin complex was similar to that of BPP7a alone, suggesting that the host-guest interaction did not strongly affect the electronic structure of the peptide. Finally, the $\mathrm{CD}$ band intensities were slightly modified due to the asymmetric interactions between $\beta$-cyclodextrin and BPP7a, indicating complex formation..$^{51,52}$

\section{Isothermal titration calorimetry}

The ITC technique was used to evaluate the thermodynamic parameters of the supramolecular interaction between BPP7a and $\beta$-cyclodextrin. Figure 3 shows the BPP7a titration curve in pure water and with $\beta$-cyclodextrin in aqueous solution. The calorimetric titration curve of BPP7a with $\beta$-cyclodextrin in solution did not show a sigmoid profile, suggesting a very weak interaction between the host and guest molecules. This result is similar to that observed in our previously work with similar systems, ${ }^{53,54}$ demonstrating a not very welldefined stoichiometry or a high equilibrium constant for this system. ${ }^{39,40}$

A lower exothermic energy was observed in the titration process of BPP7a with $\beta$-cyclodextrin than in the

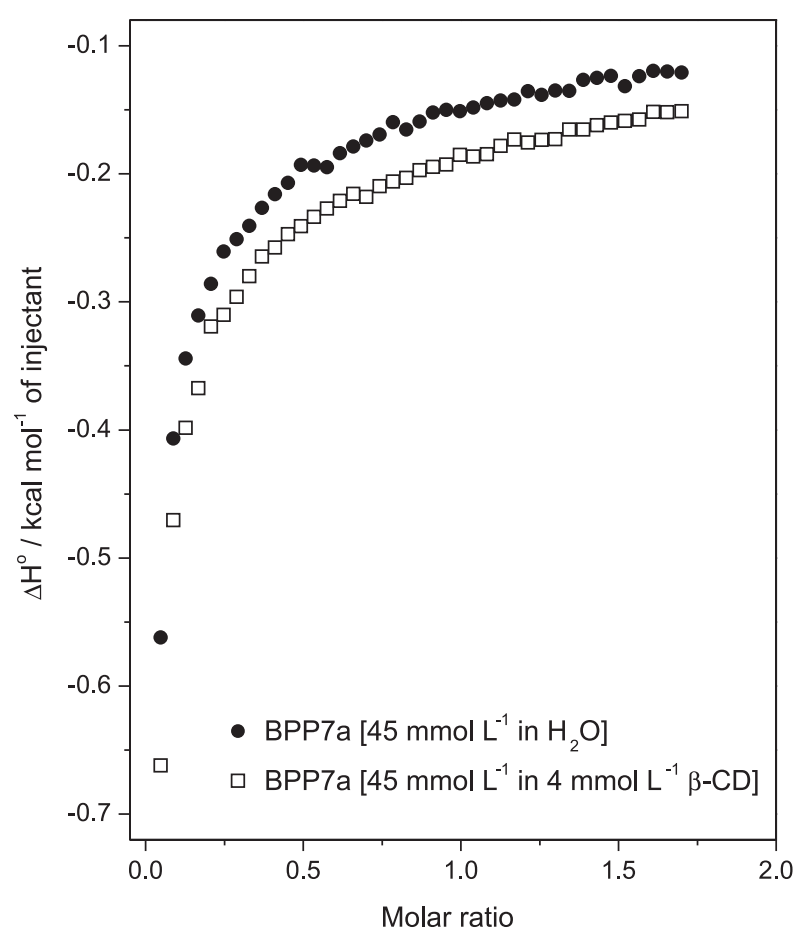

Figure 3. Calorimetric titration curves of BPP7a peptide and BPP7a/ $\beta$-cyclodextrin solutions. 
dilution of BPP7a in water. This is probably due to strong $\mathrm{BPP} 7 \mathrm{a} / \mathrm{BPP} 7 \mathrm{a}$ and $\mathrm{BPP} 7 \mathrm{a} / \mathrm{H}_{2} \mathrm{O}$ interactions, pointing to the disaggregation of the peptide molecules during the dilution process and weaker interactions between BPP7a and $\beta$-cyclodextrin than BPP7a/BPP7a interactions..$^{53}$ This enthalpy change was attributed to the desolvation process of $\beta$-cyclodextrin, as well as the formation of cooperative van der Waals interactions between the guest peptide and the cyclodextrin molecule through the hydrophobic moiety. ${ }^{55}$

\section{NMR spectroscopy}

In this study, modern NMR techniques based on gradient-pulsed fields were used to determine and assign the structures of BPP7a and BPP7a/ $\beta-C D$ complex. ${ }^{1} \mathrm{H}$ NMR experiments were carried out using presaturation techniques (Figures S1 and S2) and ${ }^{13} \mathrm{C}$ NMR resonance assignments of BPP7a were obtained by 2D shift-correlated NMR techniques (data not shown). ${ }^{29-33,37,42,45-48,54}$

The chemical shifts of the hydrogen atoms are summarized in Table S1. The ${ }^{1} \mathrm{H}$ NMR chemical shift assignment of BPP7a was performed by a sequential strategy using TOCSY and NOESY contour maps, as proposed by Wüthrich (Figures S3 and S4). ${ }^{47}$

The exchange of amide hydrogens with deuterium was monitored by comparing the ${ }^{1} \mathrm{H}$ NMR spectrum using $10 \%$ $\mathrm{D}_{2} \mathrm{O} / \mathrm{H}_{2} \mathrm{O}$ as the sample solvent with spectra obtained from a freshly prepared sample in $\mathrm{D}_{2} \mathrm{O}$ (Figure $\mathrm{S} 5$ ). The residual signals observed in the ${ }^{1} \mathrm{H}$ NMR spectrum of BPP7a in $\mathrm{D}_{2} \mathrm{O}$ allowed the designation of all amide hydrogens as fast exchange signals. ${ }^{56,57}$

Analysis of the relative intensity of some nuclear Overhauser effect (NOE) cross-peaks observed in the 2D-NOESY experiment showed approximately $120 \mathrm{NOE}$ cross-peaks, which were assigned in the contour maps obtained at $5{ }^{\circ} \mathrm{C}$ and $600 \mathrm{MHz}$. The NOEs observed were intraresidue $(\mathrm{d}=(\mathrm{i}, \mathrm{i}))$ and sequential $(\mathrm{d}=(\mathrm{i}, \mathrm{i}+1))$; the experiment did not show any medium-range or longrange NOE cross-peaks $((i, i+2),(i, i+3),(i, i+4))$ (Figure S4).

In order to understand the host-guest interactions, ${ }^{1} \mathrm{H}$ NMR experiments employing presaturation and NOESY spectra of the BPP7a/ $\beta$-cyclodextrin complex in aqueous solution were performed. Unfortunately, NOE results did not show conclusive results related to BPP $7 \mathrm{a} / \beta-\mathrm{CD}$ complex formation due to great overlap of hydrogen signals in the spectrum.Therefore, HR-DOSY experiments were also used to check host-guest interactions and to establish the self-aggregation state of BPP7a. The diffusion coefficient values suggested the involvement of peptide and $\beta$-cyclodextrin through self assembly process and the breakage of the molecular clusters by $\beta$-cyclodextrin leading to complex formation (Figure S6). ${ }^{54}$

NMR studies are suitable to monitor structural behavior in solution..$^{54}$ The NMR results indicate no defined structure in aqueous solution, in agreement with $\mathrm{CD}$ data. The ${ }^{1} \mathrm{H}$ NMR spectrum of the peptide in $\mathrm{D}_{2} \mathrm{O} / \mathrm{H}_{2} \mathrm{O}$ showed at least three sets of chemical shifts for each amino acid residue, indicating conformational inhomogeneity. Some minor additional peaks in the amide region were also observed (Figure S5).

Analysis of the TOCSY and NOESY contour maps (Figure S3) showed sequential connectivity between the amino acid residues. Despite the dispersion of the amide hydrogen chemical shifts, values from $\delta 7.50$ to $8.70 \mathrm{ppm}$ were observed with some signal overlap based on their connectivity to Asp, Gly and p-Glu.

The $\mathrm{NH} / \mathrm{N}^{2} \mathrm{H}$ exchange data enabled the identification of secondary structures in the peptide backbone. The $\mathrm{NH}$ resonances from the Asp, Gly and p-Glu residues disappeared immediately after the dissolution of BPP7a in $\mathrm{D}_{2} \mathrm{O}$. All that remained was the amide signal of the Ile residue, which also disappeared in the ${ }^{1} \mathrm{H}$ NMR spectrum obtained after $24 \mathrm{~h}$. This observation indicates no participation of these hydrogen atoms in the hydrogen bonding responsible for the stabilization of the peptide secondary structure (Figure S5).

The NOESY contour maps obtained at lower temperature $\left(5{ }^{\circ} \mathrm{C}\right)$ for the free BPP7a molecule presented several cross-peaks probably due to the decrease of the tumbling rates of the peptide backbone. The cross-peaks involve correlations among the peptide backbone protons and thus provide information regarding the peptide conformation in aqueous solution. Only intraresidual and sequential NOE cross-peaks were observed, suggesting that the peptide backbone, in solution, presents a fully extended and nonrigid conformation.

The cross-peaks observed in the NOESY contour maps also provided separation of the three proline residues of BPP7a. The NOE observed between the $\alpha$-hydrogens of Gly $\left(\delta 3.87\right.$ and 3.73) and the $\delta$-hydrogens of $\operatorname{Pro}^{4}(\delta 3.31)$ was the starting point for the identification of the $\mathrm{Pro}^{4}$ residue. The assignments of the $\operatorname{Pro}^{6}$ and Pro $^{7}$ residues were based in the NOE cross-peak observed with the $\mathrm{Ile}^{3}$ residue, specifically the NOE observed from $\gamma \mathrm{CH}_{3}-\mathrm{Ile}^{5}(\delta 0.69)$ to the $\delta$-hydrogen of $\operatorname{Pro}^{6}$ at $\delta 3.68$-3.62 (Figure S4).

The NOESY contour map of the BPP7a/ $\beta$-cyclodextrin complex, as well as the spectrum obtained for the free peptide, showed only sequential and intraresidue crosspeaks. The experiment did not show any medium- or long-range NOE cross-peaks, indicating that the peptide 
backbone continuously presents an extended and nonrigid conformation without any modifications due to complex formation. The NOESY spectrum analysis did not allow the identification of intermolecular NOE correlation between the hydrogen atoms of the $\beta$-cyclodextrin and the peptide due to the great overlap of signals between $\delta 3.00$ and 4.00..$^{58,59}$

However, based on the DOSY experiments (Figure S6), the interactions between the species in the system were verified since both molecules presented the same diffusion coefficient. This result indicates that BPP7a and $\beta$-cyclodextrin interact through hydrogen bonds, favoring the formation of a supramolecular structure that is detected as a molecular system.

The relationship between the structural properties and the diffusion coefficient arises due to the change in structure of the molecular model, as seen by the Stokes-Einstein equation (equation 2), in which the diffusion coefficient $(D)$ depends on the friction factors $(f)$ that are related to the molecular size and the solution viscosity:

$D=k \mathrm{~T} / f$

where $k$ is the Boltzmann constant and $\mathrm{T}$ is the absolute temperature. ${ }^{36}$ In order to avoid experimental error arising from variations in solution viscosity, 1,4-dioxane was used in this study as an internal viscosity standard. When analyzed independently of this internal standard, variations in diffusion coefficients may be attributed to variations in solution viscosity. This internal viscosity standard, $\mathbf{R}_{H}^{\mathrm{Re} f}$, may be considered as an internal hydrodynamic radius standard, if the effective radius $\left(\mathrm{R}_{H}^{\text {Sample }}\right)$ of the molecule under study is calculated ${ }^{60-62}$ as

$\mathbf{R}_{H}^{\text {Sample }}=\mathbf{R}_{H}^{\mathrm{Re} f} \times \mathrm{D}_{\mathrm{Re} f} / \mathrm{D}$

and follows that

$\mathrm{D} / \mathrm{D}_{\operatorname{Re} f}=\mathbf{R}_{H}^{\operatorname{Re} f} / \mathbf{R}_{H}^{\text {Sample }}$

This ratio allows for the direct comparison of values among solutions after modification of the solution composition. As the hydrodynamic radius of the standard compound is considered to be constant, any changes in the hydrodynamic radius of the solute under analysis can be attributed to modifications in molecular dimensions of the system under study. Determining the self-association state can be an important step in the structure calculation for peptides, as there can be a relatively small amount of long-range interactions and misinterpretation of intermolecular/intramolecular NOE effects can completely modify the final calculated structure. ${ }^{63}$
The association process between BPP $7 \mathrm{a}$ and $\beta$-cyclodextrin was studied by varying the concentration of the species at a constant total concentration in the DOSY experiments. Figure 4 shows the diffusion coefficients of BPP7a solutions plotted against peptide concentration in the BPP7a/ $\beta$-cyclodextrin system. The diffusion coefficients measured for the BPP7a and $\beta$-cyclodextrin solutions were higher than those observed for the BPP7a/ $\beta$-cyclodextrin system. In addition, the relative self-diffusion coefficient of the peptide increased as the concentration of $\beta$-cyclodextrin decreased, indicating an association process between the species and suggesting the involvement of both molecules in a self assembly process. These data also indicated the breakage of the peptide molecular clusters by $\beta$-cyclodextrin, leading to complex formation. These results are in agreement with those of Lima et al. ${ }^{64}$ who investigated the molecular dynamics of BPP7a in aqueous solution using the DCSCC-DFTB/UFF method.

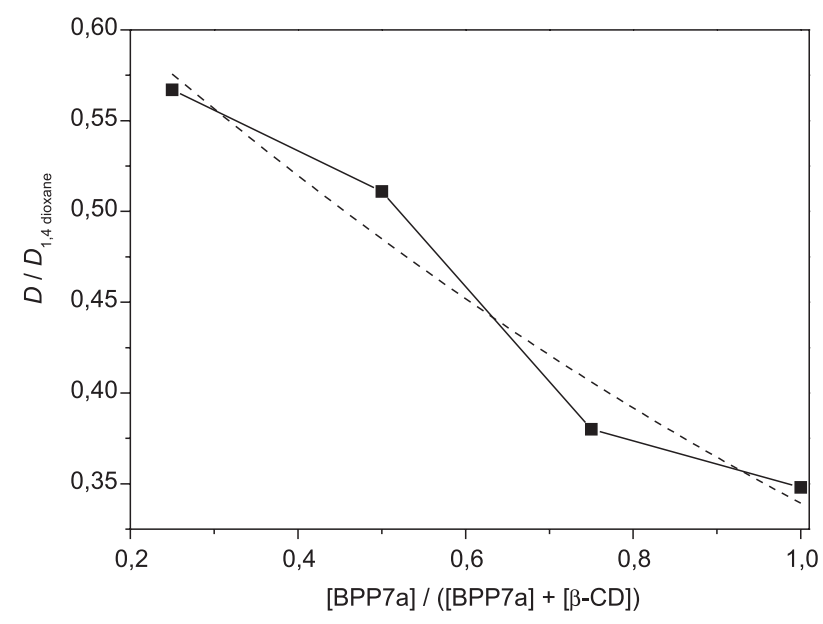

Figure 4. Diffusion coefficients for BPP7a peptide solutions against the BPP7a peptide concentration in the system BPP7a/ $\beta$-cyclodextrin in $10 \% \mathrm{D}_{2} \mathrm{O} / \mathrm{H}_{2} \mathrm{O}$ at $27^{\circ} \mathrm{C}$.

\section{Anti-hypertensive evaluation}

Figure 5 shows the MAP variation in SHR at $10 \mathrm{~min}$ intervals after oral administration of BPP7a alone or BPP7a/ $\beta$-cyclodextrin complex. The administration of $0.71 \mu \mathrm{mol}$ per $\mathrm{kg}$ of the BPP7a/ $\beta$-cyclodextrin complex decreased the MAP, starting 30 min after administration with a maximum value at $60 \mathrm{~min}(-15.1 \pm 3.4 \mathrm{~mm} \mathrm{Hg})$. The anti-hypertensive effect lasted $9 \mathrm{~h}$. By contrast, oral administration of BPP7a did not decrease the MAP. Actually, a small but significant increase in the MAP was observed in response to BPP7a not inside $\beta$-cyclodextrin. These data suggest that complexation of BPP7a in $\beta$-cyclodextrin can be used to prepare BPP formulations for oral activity. 

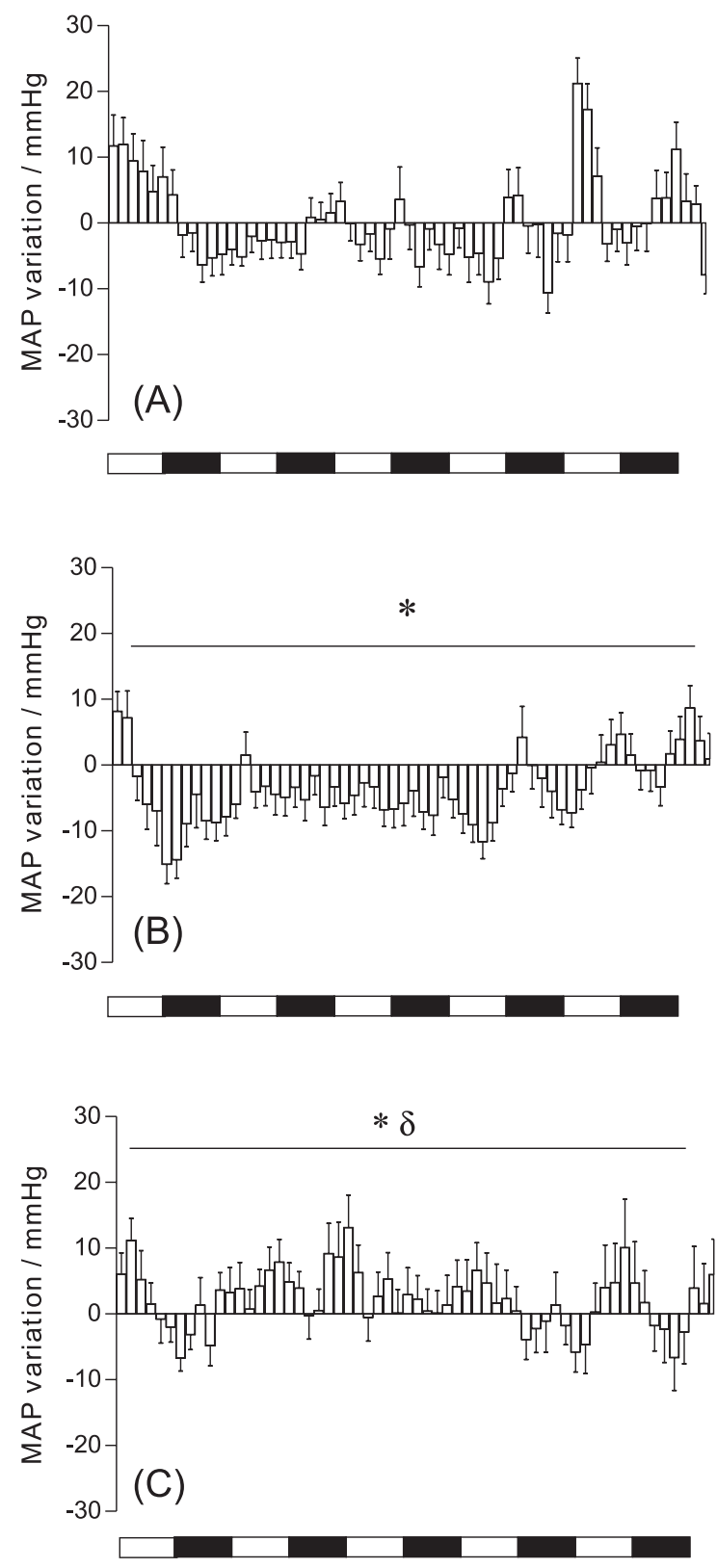

Figure 5. Mean arterial pressure variation of SHR after BPP7a or BPP7a/ $\beta$-cyclodextrin oral administration: (A) vehicle $(n=5)$, (B) BPP7a/ $/$-CD $(n=5)$ and $(\mathrm{C}) \mathrm{BPP} 7 \mathrm{a}(n=4)$. The bars show the mean variation each $10 \mathrm{~min}$. Each bar at the bottom of the figure (black and white) represents $1 \mathrm{~h}$ of record. ${ }^{*} p=0.00010$ in comparison to vehicle; $\delta p=0.0001$ in comparison to BPP7a.

\section{Conclusions}

In solution, BPP7a exists in a fully extended and nonrigid conformation, as indicated by the $\mathrm{CD}$ spectrum and NMR experiments. The complexation of BPP7a with $\beta$-cyclodextrin was achieved using the freeze-drying method. In order to confirm the interaction between BBP7a and $\beta$-cyclodextrin and the self-assembly process of BBP7a, HR-DOSY experiments were carried out in aqueous solution. The interaction process was able to break the molecular clusters of BPP7a leading to complex formation. In addition, in vivo experiments showed that the complex reduced blood pressure in SHR, a result that may be attributed to an increase in the bioavailability of BPP7a after its complexation with $\beta$-cyclodextrin.

\section{Supplementary Information}

NMR data (Figures S1-S6; Table S1) are available free of charge at http://jbcs.sbq.org.br as a PDF file.

\section{Acknowledgments}

The authors would like to acknowledge the Fundação de Amparo à Pesquisa do Estado de Minas Gerais (FAPEMIG), the Conselho Nacional de Desenvolvimento Científico e Tecnológico (CNPq) and INCT-Nanobiofar (CNPq/MCT/ FAPEMIG) for financial support and the COINFAR Pesquisa e Desenvolvimento Ltda for providing the BPP7a peptide for research. NMR facilities at $600 \mathrm{MHz}$ were supported by LNLS - the Brazilian Synchrotron Light Laboratory/MCT.

\section{References}

1. Ferreira, S. H.; Silva, M. R.; Experientia 1965, 21, 347.

2. Ferreira, S. H.; Bartelt, D. C.; Greene, L. J.; Biochemistry 1970, 9, 2583

3. Cushman, D. W.; Cheung, H. S.; Sabo, E. F.; Ondetti, M. A.; Biochemistry 1977, 16, 5484.

4. Cushman, D.W.; Ondetti, M. A.; Prog. Med. Chem. 1980, 17, 41.

5. Ondetti, M. A.; Rubin, B.; Cushmam, D. W.; Science 1977, 196, 441.

6. Hayashi, M. A.; Murbach, A. F.; Ianzer, D.; Portaro F. C.; Prezoto B. C.; Fernandes, B. L.; Silveira, P. F.; Silva, C. A.; Pires, R. S.; Britto, L. R.; Dive, V.; Camargo, A. C. M.; J. Neurochem. 2003, 85, 969.

7. Gomes, C. L.; Konno, K.; Conceição, I. M.; Ianzer, D.; Yamanouye, N.; Prezoto, B. C.; Assakura, M. T.; Rádis-Baptista, G.; Yamane, T.; Santos, R. A.; Camargo, A. C. M.; Hayashi, M. A. F.; Biochem. Pharmacol. 2007, 74, 1350.

8. Ianzer, D.; Konno, K.; Marques-Porto, R.; Portaro, F. C. V.; Stocklin, R.; Camargo, A. C. M.; Pimenta, D. C.; Peptides 2004, 25,1085 .

9. Ianzer, D.; Santos, R. A. S.; Etelvino, G. M.; Xavier, C. H.; Santos, J. A.; Mendes, E. P.; Machado, L. T.; Prezoto, B. C.; Dive, V.; Camargo, A. C. M.; J. Pharmacol. Exp. Ther. 2007, 322, 795.

10. Kumar-Malik, D.; Sanjula, B.; Alka, A.; Sohail1, H.; Javed, A.; Curr. Drug Delivery 2007, 4, 141. 
11. Rubstein, A.; Tirosh, B.; Baluom, M.; Nassar, T.; David, A.; Radai, R.; Gliko-Kabir, I.; Friedman M.; J. Controlled Release 1997, 46, 59.

12. Sinha, V. R.; Kumria, R.; Int. J. Pharm. 2001, 224, 19.

13. Del Valle, E. M.; Process Biochem. (Amsterdam, Neth.) 2004, 39, 1033.

14. Irie, T.; Uekama, K.; Adv. Drug, Delivery Rev. 1999, 36, 101.

15. Loftsson, T.; Cyclodextrins in Pharmaceutical Formulations: the Effects of Polymers on their Complexation Efficacy and Drug Availability; a report for Nordic Industrial Fund: Reykjavik, Iceland, 1988.

16. Thompson, D. O.; Crit. Rev. Ther. Drug 1997, 14, 1.

17. Uekama, K.; J. Inclusion Phenom. Macrocyclic Chem. 2002, 44,3 .

18. Uekama, K.; Hirayama, F.; Irie, T.; Chem. Rev. 1998, 98, 2045.

19. Szejtli, J.; Chem. Rev. 1998, 98, 1743.

20. Liu, Y.; Tetrahedron Lett. 2007, 48, 3871.

21. Higuchi, T.; Connors, K. A.; Adv. Anal. Chem. Instrum. 1965, 4, 117.

22. Uekama, K.; Horiuchi, Y.; Kikuchi, M.; Hirayama, F.; Ijitsu, T.; Ueno, T.; J. Inclusion Phenom. Macrocyclic Chem. 1988, 6, 167.

23. De Sousa, F. B.; Denadai, A. M. L.; Lula, I. S.; Lopes, J. F.; Santos, H. F.; Almeida, W. B.; Sinisterra, R. D.; Int. J. Pharm. 2008, 353, 160.

24. De Sousa, F. B.; Denadai, A. M. L.; Lula, I. S.; Nascimento, C.; Fernandes-Neto, N. S. G.; Lima, A. C.; Almeida, W. B.; Sinisterra, R. D.; J. Am. Chem. Soc. 2008, 130, 8426.

25. De Sousa, F. B.; Oliveira, M. F.; Lula, I. S.; Sansiviero, M. T. C.; Cortés, M. E.; Sinisterra, R. D.; Vib. Spectrosc. 2008, 46, 57.

26. Reed, J.; Reed, T. A.; Anal. Biochem. 1997, 254, 36.

27. Andrushchenko, V. V.; Vogel, H. J.; Prenner, E. J.; Biochim. Biophys. Acta, Biomembr. 2006, 1758, 1596.

28. Fanghänel, J.; Wawra, S.; Lücke, C.; Wildemann, D.; Fischer, G.; Anal. Chem. 2006, 78, 4517.

29. Bax, A.; Davis, D. G.; J. Magn. Reson. 1985, 65, 355.

30. Braun, S.; Kalinowski, H.-O.; Berger, S.; 150 and More Basic NMR Experiments: a Pratical Course; Wiley-VCH: New York, 1988.

31. Derome, A. E.; Modern NMR Techniques for Chemistry Research; Pergamon Press: London, 1987.

32. Bax, A.; Davis, D. G.; J. Magn. Reson. 1985, 63, 207.

33. Gil, V.; Geraldes, C. F. G. C.; Ressonância Magnética Nuclear: Fundamentos, Métodos e Aplicações; Fundação Calouste Gulbenkian: Lisboa, Portugal, 1987.

34. Braunschweiler, L.; Schweiger, A.; Fauth, J. M.; Ernst, R. R.; J. Magn. Reson. 1985, 64, 160.

35. Stejskal, E. O.; Tanner, J. E.; J. Chem. Phys. 1965, 42, 288.

36. Johnson Jr., C. S.; Prog. Nucl. Magn. Reson. Spectrosc. 1999 , $34,203$.

37. Greenfield, N.; Fasman, G. D.; Biochemistry 1969, 8, 4108.
38. http://chemistry.rutgers.edu/grad/chem585/lecture1.html, Circular Dichroism Spectroscopy of Biomolecules, accessed in 2007.

39. Turnbull, W. B.; Daranas, A. H.; J. Am. Chem. Soc. 2003, 125, 14859.

40. http://www.uic.edu/orgs/ctrstbio/manuals/vpitc_manual.pdf, MicroCalorimeter: User's Manual. MicroCal - The Calorimetry Experts, $5^{\text {th }}$ ed., Northampton, 1998, accessed in 2007.

41. Denadai, A. M. L.; Santoro, M. M.; Silva, L. H.; Viana, A. T.; Santos, R. A. S.; Sinisterra, R. D.; J. Inclusion Phenom. Macrocyclic Chem. 2006, 55, 41.

42. Piotto, M.; Saudek, V.; Sklenár, V.; J. Biomol. NMR 1992, 2, 661.

43. Pelta, M. D.; Barjat, H.; Morris, A. G.; Davis, A. L.; Hammond, S. J.; Magn. Reson. Chem. 1998, 36, 706.

44. Tanner, J. E.; J. Chem. Phys. 1970, 52, 2523; Tillet, M. L.; Lian, L.-Y.; Norwood, T. J.; J. Magn. Reson. 1998, 133, 379.

45. Delaglio, F.; Grzesiek, S.; Vuister, G. W.; Zhu, G.; Pfeifer, J.; Bax, A.; J. Biomol. NMR 1995, 6, 277.

46. Markley, J. L.; Bax, A.; Arata, Y.; Hilbers, C. W.; Kaptein, R.; Sykes, B. D.; J. Mol. Biol. 1998, 280, 933.

47. Wüthrich, K.; NMR of Protein and Nucleic Acids; Wiley Interscience: New York, 1986.

48. Zimmerman, D. E.; Montelione, G.; Curr. Opin. Struc. Biol. 1995, 5, 664 .

49. Brooks, D.; Horner, R. L.; Kozar, L. F.; Waddell, T. K.; Render, C. L.; Phillipson, E. A.; J. Appl. Physiol. 1996, 81, 1012.

50. http://www.graphpad.com/prism, accessed in 2007.

51. Kobayashi, N.; Osa, T.; Bull. Chem. Soc. Jpn. 1991, 64, 1878.

52. Kodaka, M.; J. Phys. Chem. 1991, 95, 2110.

53. Denadai, A. M. L.; Ianzer, D.; Alcântara, A. F. C.; Santoro, M. M.; Santos, C. F. F.; Lula, I. S.; Camargo, A. C. M.; Faljoni-Alario, A.; Santos, R. A. S.; Sinisterra, R. D.; Int. J. Pharm. Chem. 2007, 336, 90.

54. Lula, I.; Denadai, A. L.; Resende, J. M.; De Sousa, F. B.; Lima, G. F.; Pilo-Veloso, D.; Heine, T.; Duarte, H. A.; Santos, R. A. S.; Sinisterra, R. D.; Peptides 2007, 28, 2199; Lima, G. F.; Heine, T.; Duarte, H. A.; Macromolecular Symposia 2007, 254, 80; De Sousa, F. B.; Denadai, A. L.; Lula, I.; Ianzer, D.; Malaspina, E. R.; Camargo, A. C. M.; Santos, R. A. S.; Sinisterra, R. D.; J. Inclusion Phenom. Macrocyclic Chem. 2010, 407,67.

55. Rekharsky, M.; Inoue, Y.; Tobey, S.; Metzger, A.; Anslyn, E.; J. Am. Chem. Soc. 2002, 124, 14959.

56. Cushman, J. A.; Mishra, P. K.; Bothner-By, A. A.; Khosla, M. S.; Biopolymers 1992, 32, 1163.

57. Davy, S. L.; Osborne, M. J.; Moore, G. R.; J. Mol. Biol. 1998, 277, 683.

58. Schneider, H.-J.; Hacket, F.; Rüdiger, V.; Ikeda, H.; Chem. Rev. 1998, 98, 1755.

59. Johnson Jr., C. S.; Prog. Nucl. Magn. Reson. Spectrosc. 1999, 34, 203. 
60. Cabrita, E. J.; Berger, S.; Magn. Reson. Chem. 2001, 39, S142.

61. Wilkins, D. K.; Grimshaw, S.B.; Receveur, V.; Dobson, C. M.; Jones, J. A.; Smith, L. J.; Biochemistry 1999, 38, 16424.

62. Yao, S.; Howlett, G. J.; Norton, R. S.; J. Biomol. NMR 2000 , 16, 109.

63. Altieri, A. S.; Hinton, D. P.; Byrd, R. A.; J. Am. Chem. Soc. 1995, 117, 7566 .
64. Lima, G. F.; Heine, T.; Duarte, H. A. In Advances in Quantum Chemistry, vol. 59; Sabin, J. R.; Brändas, E., eds.; Academic Press: Florida, 2010, ch. 5.

Submitted: December 23, 2010

Published online: June 30, 2011

FAPESP has sponsored the publication of this article. 


\title{
Study of the BPP7a Peptide and its $\beta$-Cyclodextrin Complex: Physicochemical Characterization and Complete Sequence Specific NMR Assignments
}

\author{
Ivana Lula, ${ }^{a}$ Frederico B. de Sousa, ${ }^{a}$ Ângelo M. L. Denadai, ${ }^{a, c}$ Danielle Ianzer, ${ }^{b, d}$ \\ Antônio C. M. de Camargo, ${ }^{d}$ Robson A. S. Santos ${ }^{b}$ and Rubén D. Sinisterra ${ }^{*, a}$ \\ ${ }^{a}$ Departamento de Química, Instituto de Ciências Exatas and ${ }^{b}$ Departamento de Fisiologia e \\ Biofísica, Instituto de Ciências Biológicas, Universidade Federal de Minas Gerais, \\ Av. Antonio Carlos, 6621, 31270-901 Belo Horizonte-MG, Brazil \\ ${ }^{c}$ Centro Federal de Educação Tecnológica (CEFET-MG, Campus VII), Av. Amazonas, 1193, \\ Vale Verde, 35183-006 Timóteo-MG, Brazil \\ ${ }^{d}$ Center for Applied Toxinology (CAT-CEPID), Instituto Butantã, Av. Vital Brasil, 1500, \\ 05503-900 São Paulo-SP, Brazil
}

Table S1. ${ }^{1} \mathrm{H}$ NMR $(600 \mathrm{MHz})$ spectral data for $\mathrm{BPP} 7 \mathrm{a}, 5^{\circ} \mathrm{C}\left(10 \% \mathrm{D}_{2} \mathrm{O} / \mathrm{H}_{2} \mathrm{O}\right)$

\begin{tabular}{|c|c|c|c|c|c|}
\hline Residue & $\delta \mathrm{NH}$ & $\delta \alpha-\mathrm{H}$ & $\delta \beta-\mathrm{H}$ & & $\delta$ others \\
\hline p-Glu & 7.74 & 4.03 & $\beta \mathrm{CH}_{2} 2.13$ & $\gamma \mathrm{CH}_{2}$ & $2.24-2.29$ and $1.77-1.83$ \\
\hline $\mathrm{Asp}^{\mathrm{a}}$ & $8.51(8.48)$ and (8.30) & 4.54 & 2.67 and 2.51 & & - \\
\hline Gly $^{\mathrm{a}}$ & $8.09(8.06)$ & $\alpha \mathrm{CH}_{2} 3.87$ and 3.73 & - & & - \\
\hline $\operatorname{Pro}^{b}$ & - & 4.10 & $\begin{array}{l}1.53-1.59 \text { and } \\
1.91-1.99\end{array}$ & $\begin{array}{l}\gamma \mathrm{CH}_{2} \\
\delta \mathrm{CH}_{2}\end{array}$ & $\begin{array}{c}2.02-2.12 \text { and } 1.55-1.65 \\
3.31\end{array}$ \\
\hline $\mathrm{Ile}^{\mathrm{a}}$ & $\begin{array}{c}8.21(7.74) \\
(8.26) \text { and }(8.43)\end{array}$ & 4.14 & $1.58-1.53$ & $\begin{array}{l}\gamma \mathrm{CH}_{2} \\
\gamma \mathrm{CH}_{3} \\
\delta \mathrm{CH}_{3}\end{array}$ & $\begin{array}{c}0.91 \text { and } 1.26 \\
0.69 \\
0.59\end{array}$ \\
\hline $\operatorname{Pro}^{\mathrm{b}}$ & - & 4.38 & 1.74 & $\begin{array}{l}\gamma \mathrm{CH}_{2} \\
\delta \mathrm{CH}_{2}\end{array}$ & $\begin{array}{c}1.69-1.73 \\
3.68-3.62 \text { and 3.34-3.43 }\end{array}$ \\
\hline $\operatorname{Pro}^{\mathrm{b}}$ & - & 4.07 & 1.72 & $\begin{array}{l}\gamma \mathrm{CH}_{2} \\
\delta \mathrm{CH}_{2}\end{array}$ & $\begin{array}{l}1.99-2.04 \text { and } 1.78-1.70 \\
3.45-3.56 \text { and } 3.34-3.41\end{array}$ \\
\hline
\end{tabular}

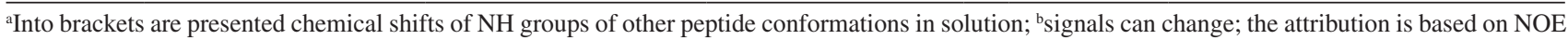
results. 


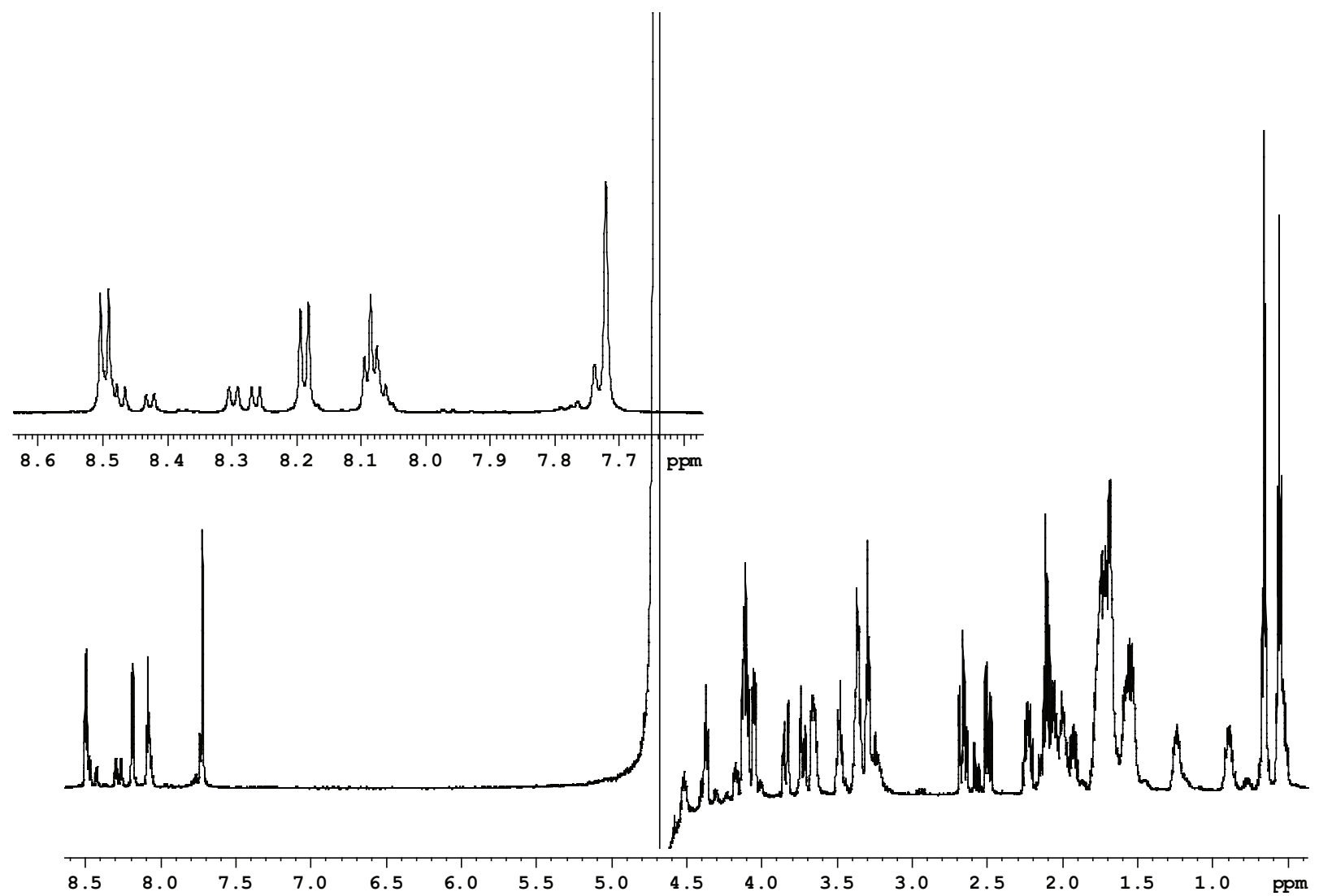

Figure S1. ${ }^{1} \mathrm{H}$ NMR spectrum of BPP7a peptide at $5{ }^{\circ} \mathrm{C}$ (presaturation, $600 \mathrm{MHz}, 10 \% \mathrm{D}_{2} \mathrm{O} / \mathrm{H}_{2} \mathrm{O}$ ), including expansion of amidic and aromatic region (upper portion).

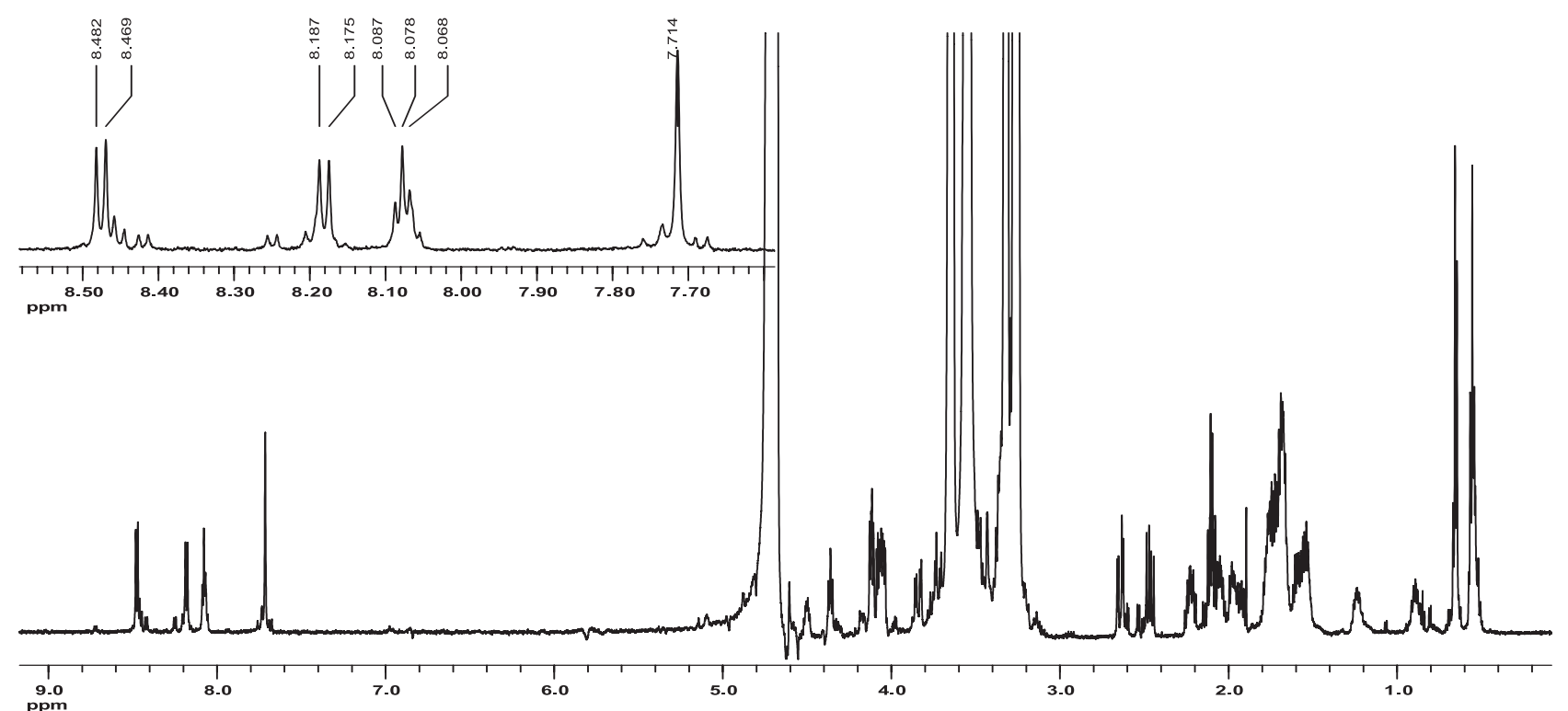

Figure S2. ${ }^{1} \mathrm{H}$ NMR spectrum of the $\mathrm{BPP} 7 \mathrm{a} / 3$-cyclodextrin complex at $5{ }^{\circ} \mathrm{C}$ (presaturation, $600 \mathrm{MHz}, 10 \% \mathrm{D}_{2} \mathrm{O} / \mathrm{H}_{2} \mathrm{O}$ ), including expansion of amidic and aromatic region (upper portion). 

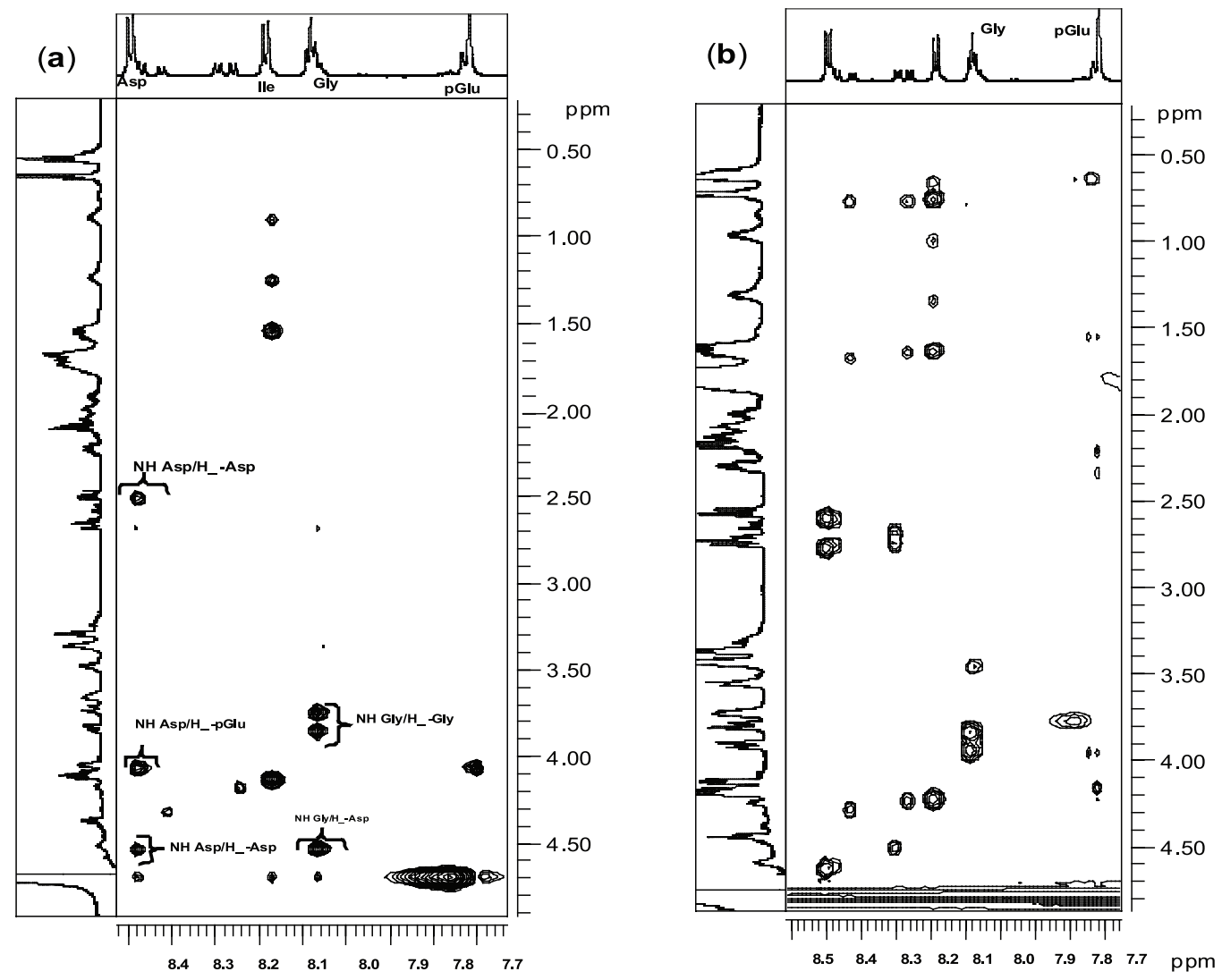

Figure S3. Amide region of ${ }^{1} \mathrm{H}$ NMR spectra of the BPP7a peptide at $5{ }^{\circ} \mathrm{C}\left(600 \mathrm{MHz}, 10 \% \mathrm{D}_{2} \mathrm{O} / \mathrm{H}_{2} \mathrm{O}\right)$ (a) NOESY contour map of the amidic region, with a mixing time of $230 \mathrm{~ms}$ and (b) TOCSY contour map of amidic region, with a mixing time of $85 \mathrm{~ms}$.

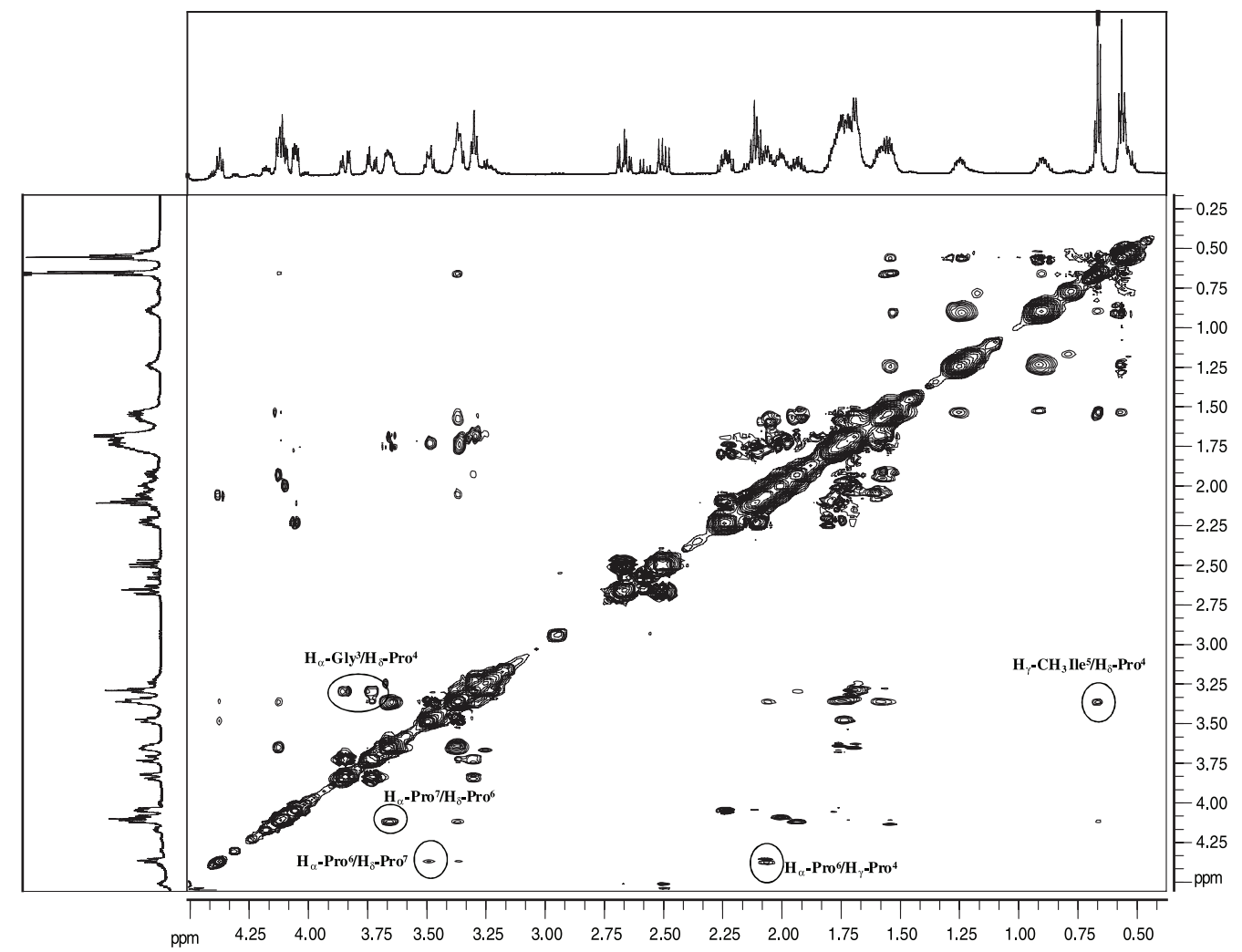

Figure S4. NOESY contour map of BPP7a at $5{ }^{\circ} \mathrm{C}\left(600 \mathrm{MHz}, 10 \% \mathrm{D}_{2} \mathrm{O} / \mathrm{H}_{2} \mathrm{O}\right)$. For clarity, NOE correlations of Pro residues are indicated. 
(c)

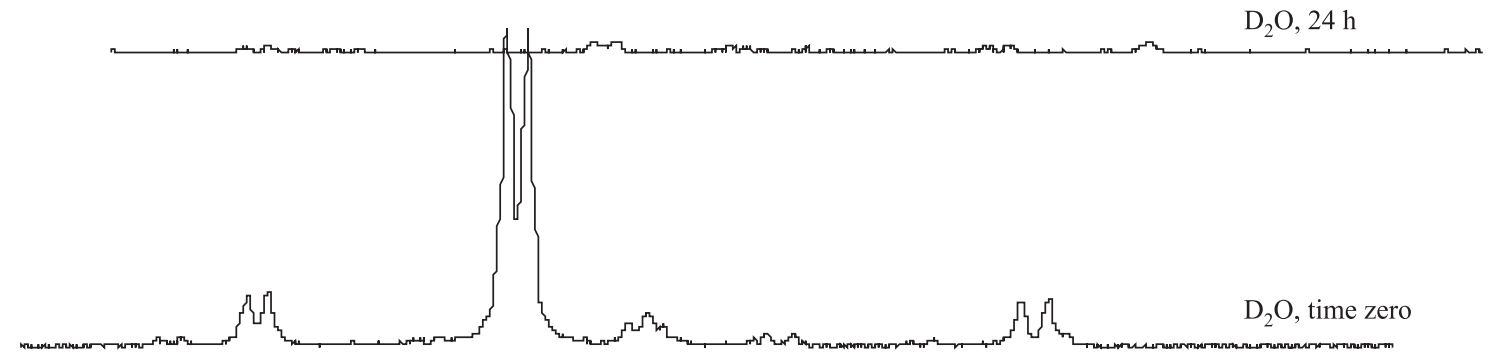

(b)

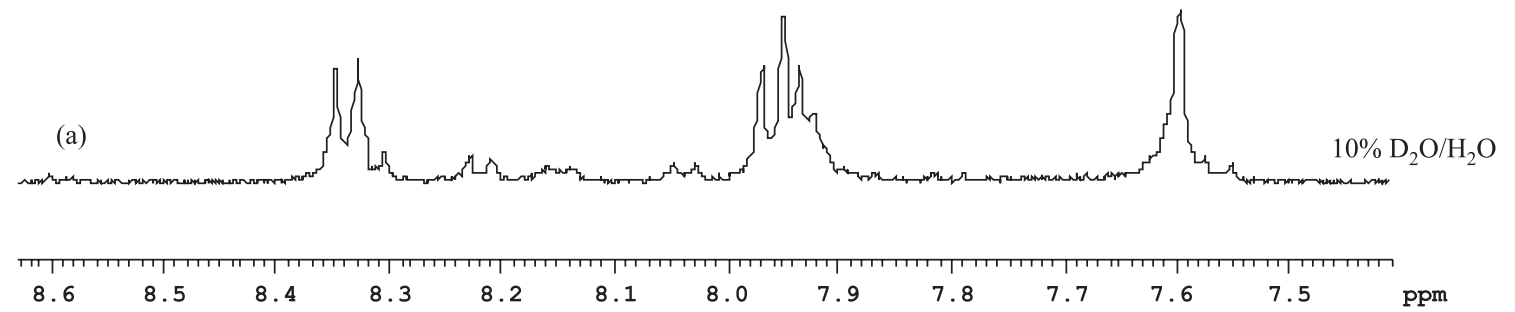

Figure S5. Amide region of ${ }^{1} \mathrm{H}$ NMR spectra of the BPP7a peptide at $5{ }^{\circ} \mathrm{C}, 400 \mathrm{MHz}$ (a) $10 \% \mathrm{D}_{2} \mathrm{O} / \mathrm{H}_{2} \mathrm{O}$, (b) $\mathrm{D}_{2} \mathrm{O}$, freshly prepared solution and (c) $\mathrm{D}_{2} \mathrm{O}$, $24 \mathrm{~h}$ after solution preparation.
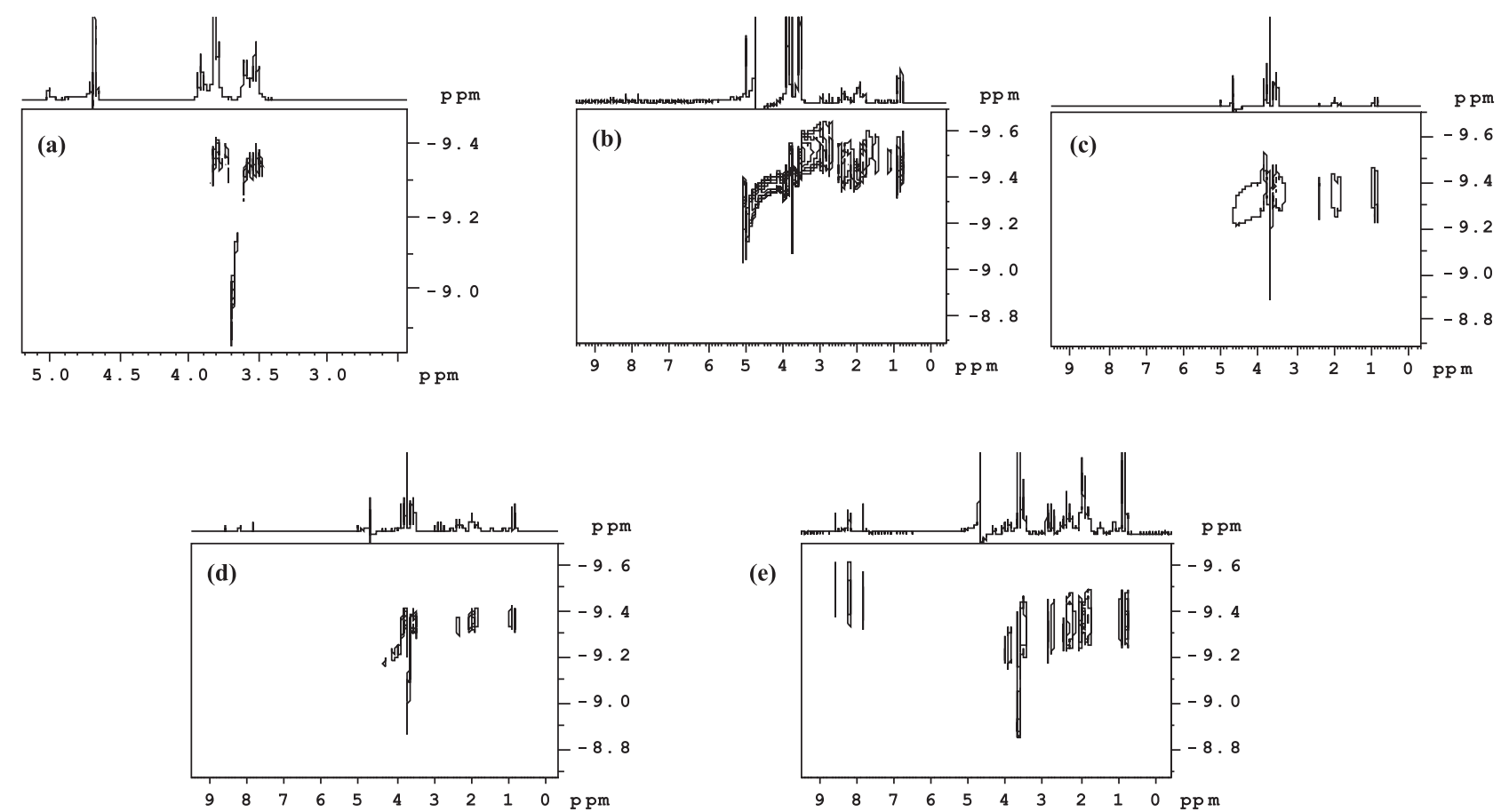

Figure S6. DOSY plots at $400 \mathrm{MHz}$ in $\mathrm{D}_{2} \mathrm{O} / \mathrm{H}_{2} \mathrm{O}$ for the supramolecular system BPP7a/ $\beta$-cyclodextrin: (a) $\mathrm{BPP} 7 \mathrm{a} / \beta$-cyclodextrin $\left[8\right.$ mmol $\mathrm{L}^{-1}$ ],

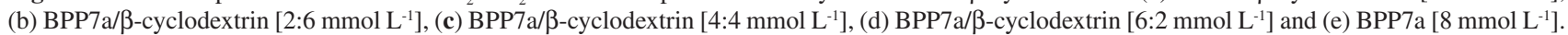
Experimental conditions: $10 \% \mathrm{D}_{2} \mathrm{O} / \mathrm{H}_{2} \mathrm{O}, 27^{\circ} \mathrm{C}, 400 \mathrm{MHz}$. 